\title{
Occurrence of vaccine abscesses in bovines after the administration of bivalent foot-and-mouth disease vaccine
}

\section{Ocorrência de abscessos vacinais em bovinos após aplicação da vacina antiaftosa bivalente}

\author{
CANDEIRA, Willy Kelvin ${ }^{1}$ \\ 0000-0002-8106-3753
}

FONSECA, Luciano Santos da ${ }^{2}$

0000-0002-7463-6322

ARRUDA, Roberto Carlos Negreiros de $\mathrm{e}^{3}$ 0000-0003-2982-6052
FREITAS, Layza Michelle de Azevedo ${ }^{4}$ 0000-0003-4450-7711

SILVA, Hilmanara Tavares da ${ }^{5}$ 0000-0001-5997-8554

COIMBRA, Viviane Correa Silva ${ }^{1 *}$ 0000-0001-7611-6673

\footnotetext{
${ }^{1}$ State University of Maranhão, Animal Health Defense Program, São Luís, Maranhão, Brazil; ${ }^{2}$ State University of Tocantina Region of Maranhão, Imperatriz, Maranhão, Brazil;

${ }^{3}$ Federal Superintendence of Agriculture, Livestock and Supply of Maranhão, São Luís, Maranhão, Brazil;

${ }^{4}$ State Agency of Livestock Defense in Maranhão, São Luís, Maranhão, Brazil;

${ }^{5}$ Municipal Agriculture, Fish and Supply Secretariat of São Luís, São Luís, Maranhão, Brazil;

*Corresponding author: vivianecorrea@yahoo.com
}

\begin{abstract}
The aim of the present study is to identify the occurrence of abscesses in cattle after the administration of bivalent foot-and-mouth disease vaccine as adverse reaction to components in the new commercial vaccine formulation. Thirty bovines were divided into three groups composed of 10 animals, each. Groups 1 and 2 were vaccinated by researchers based on good vaccination practices criteria. Group 1 was intramuscularly administered with the vaccine, Group 2 received it through subcutaneous route and Group 3 was vaccinated by breeders through subcutaneous route. Animals were selected and observed in vivo in three different moments (7, 28 and 45 days after vaccination). Subsequently, they were observed during post mortem inspection in order to assess the occurrence of vaccine abscesses. Vaccine abscesses were recorded in $40 \%$ of bovines in Group 1, in $50 \%$ of the ones in Group 2 and in $60 \%$ of those in Group 3. There was no significant difference between experimental groups based on the Chi-square test and on Cramer's V analysis; there was no significant difference among experimental groups. Excess of carcass parts presenting vaccine abscesses during post mortem inspection resulted in the meat loss of $1.775 \mathrm{~kg}$ in Group 1, of $2.303 \mathrm{~kg}$ in Group 2 and of $3.268 \mathrm{~kg}$ in Group 3. In conclusion, despite changes in bivalent foot-and-mouth disease vaccine formulation, care should be taken at vaccination time to minimize the occurrence of
\end{abstract}


vaccine abscesses and, consequently, meat losses at slaughter, as well as to reduce losses in beef production chain.

Keywords: bovines, vaccination, nodules, post-vaccine reaction.

\section{RESUMO}

O presente estudo objetivou identificar a ocorrência de abcessos em bovinos após a aplicação da vacina antiaftosa bivalente, como reação adversa aos componentes da nova formulação comercial. Foram avaliados 30 bovinos divididos em três grupos de 10 animais. Os Grupos 1 e 2 foram vacinados pelos pesquisadores seguindo os critérios de boas práticas de vacinação, sendo o Grupo 1 vacinado pela via intramuscular e o Grupo 2 pela via subcutânea, já o Grupo 3 foi vacinado pelo produtor rural utilizando a via subcutânea. Os animais foram isolados e observados in vivo em três momentos $\left(7^{\circ}, 28^{\circ} \mathrm{e}\right.$ $45^{\circ}$ dias após a vacinação), em seguida foram observados durante a inspeção post mortem para constatação da ocorrência de abscessos vacinais. Registrou-se a ocorrência de abscessos vacinais em $40 \%$ dos bovinos do Grupo 1, em 50\% do grupo 2 e em $60 \%$ do grupo 3. Não houve diferença significativa entre os grupos experimentais segundo o teste do Qui-quadrado e a análise do $\mathrm{V}$ de Cramer. A partes cárneas excisadas das carcaças com abcessos vacinais durante a inspeção post mortem resultaram em uma perda cárnea de $1.775 \mathrm{~kg}$ no Grupo 1, de $2.303 \mathrm{~kg}$ no Grupo 2 e de $3.268 \mathrm{~kg}$ no Grupo 3. Conclui-se, que mesmo com a alteração da formulação da vacina antiaftosa, são necessários cuidados no ato da vacinação, a fim de minimizar a ocorrência de abscessos vacinais e consequentes perdas cárneas no ato do abate dos animais, diminuindo assim os prejuízos à cadeia produtiva da carne.

Palavras-Chave: bovinos, vacinação, nódulos, reação pós-vacinal. 


\section{INTRODUCTION}

Foot-and-mouth disease is the animal illness accountable for strong economic impact on the livestock sector. Losses caused by severe clinical signs of it, mainly losses due to the impossibility to act in the foreign market because of embargoes by beef importer countries, which lead to socioeconomic losses (GARCIA et al., 2015).

The upward direction of the Brazilian beef market for exports reflects sanitary control programs adopted in the country to mitigate illnesses that have great diffusion power and economic impact. The National Foot-and-Mouth Disease Program (PNEFA) developed several measures to control and eradicate the disease. Among them, one finds the systematic compulsory vaccination based on the schedule set by the Ministry of Agriculture, Livestock and Supply (MAPA), which turned the use of vaccination as routine management for breeders (SILVA et al., 2018).

However, the use of vaccines with oil compounds can lead to adverse reactions including post-vaccination granulomas, tissue damage, hypersensitivity reactions and consequent inflammatory reactions. These compounds catalyze abscess formation and depreciate the carcasses, or part of them, which leads to significant economic losses in the production chain (MORO et al., 2001; FRANÇA FILHO et al., 2006; AMORIM et al., 2009).

In 2018, MAPA developed a new formulation for the foot-and-mouth disease vaccine, which allowed reducing vaccine dose. The vaccine became bivalent, since it got two purified inactive and emulsified antigens in its composition - O1 (Campos) and A24 (Cruzeiro). The vaccine dose was reduced from $5 \mathrm{ml}$ to $2 \mathrm{ml}$; oil compound saponin was removed from the formulation in order to reduce abscess formation and consequent losses caused by the loss of carcasses, or of part of them (BRASIL, 2018).

The assessment of high economic losses caused by the presence of abscesses in the muscles in bovine carcasses brings along the need of reasoning about the management practices adopted for both vaccination and administration of other medicines, since Brazil is the greatest beef exporter in the world. The country recorded 826.1 thousand tons of exported beef (MONTE et al., 2018).

Thus, the aim of the present study was to identify the occurrence of abscesses in bovines after foot-and-mouth disease vaccination as adverse response to compounds in the new bivalent commercial formulation authorized by the Ministry of Agriculture, Livestock and Supply.

\section{MATERIALS AND METHODS}

Experimental, longitudinal, prospective study with non-probabilistic intentional sampling set to identify the occurrence of adverse reactions after cattle vaccination against foot-and-mouth disease with the bivalent vaccine formulation. Study site was Santa Rita County - MA, which counts on 16,186 cattle heads distributed into 174 rural properties based on data recorded during the vaccination campaign against foot-and-mouth disease carried out in May 2019, by State Agency of Animal Health Defense AGED/MA (MARANHÃO, 2019). 
A rural property identified as Farm " $\mathrm{X}$ " was selected for the experimental study, its owner practices extensive breeding of Nellore cattle. He follows regular semiannual registers of vaccination against food-and-mouth disease, and his property does not have history of its occurrence. After being informed about the aim and stages of the research, the owner signed the clarification term and free consent - TELC, and authorized research conduction in his farm.

In total, 30 bovines were randomly selected - all females of the Nellore breed in the age group 36 to 42 months, and body weight between 350 and $450 \mathrm{Kg}$, without lesions in the neck board (vaccine administration region). After selection, the animals were individually labeled with numbered year rings; next, they were divided into three experimental groups comprising 10 (ten) bovines, each; namely: Group 1 (G1), Group 2 (G2) and Group 3 (G3).

Bivalent food-and-mouth vaccines containing purified, inactive and emulsified antigens of the $\mathrm{O} 1$ (Campos) and A24 (Cruzeiro) types were purchased in registered retailers authorized by the official sanitary defense bureau. They were stored at temperature ranging from $2^{\circ} \mathrm{C}$ to $8^{\circ} \mathrm{C}$, based on manufacture's recommendations. After purchase, vaccines were taken to the study site in isothermal boxes filled with recycling ice (used to keep the conservation temperature), based on the Good Bovine Vaccination and Immunization Practices Handbook by EMBRAPA (GASPAR et al., 2015).

Animals were kept in beta for cattle contention; vaccination was carried out after contention, with the aid of properly sanitized vaccination pistol calibrated for $2 \mathrm{~mL}$ shots. Vaccination in groups 1 and 2 was conducted by researchers, whereas in Group 3, it was carried out by farm personnel. Vaccine was administered at the middle third of the neck board, on the right side of each animal.

Vaccination in each experimental group happened as follows: i) G1 intramuscular route, with the aid of needle at caliber 20x8; ii) G2 subcutaneous route, with the aid of needle at caliber $10 \times 15$; iii) G3 subcutaneous route, according to practices adopted by the breeder.

After vaccination, animals remained in isolated picket for "observation in vivo" for 45 days; they were inspected in three different moments: i) first observation session -7 days after vaccination; ii) second observation session - 28 days after vaccination and iii) third observation session - 45 days after vaccination. The assessment was carried out through direct observation and palpation of the neck board. The size and shape of the observed abscesses were evaluated. Measurements were taken with measuring tape on the bigger abscess axis.

After the "observation in vivo" period was over, animals were sent to slaughter in slaughterhouse registered in the municipal inspection service (SIM) for "post-mortem inspection". The carcasses were evaluated for the occurrence, or not, of abscesses in the vaccine administration region. This study stage was carried out along with the inspector veterinary of the slaughterhouse at inspection line I, where the internal and external sides of the cranial part (rear side) of the carcass was assessed, as well as the pre-scapular nodules, in order to 
identify any local granulomatous reaction.

The observed abscesses were subjected to excision based on criteria established in Art. N. 134 of the Regulation of Industrial and Sanitary Inspection of Animal Origin Products - RIISPOA (BRASIL, 2017). Discharges from excision were stored on trays and previously weighed on scale; results were recorded in specific spreadsheet.

Data collected through post-vaccination "observation in vivo" and during "postmortem inspection" were processed and followed by analysis and interpretation. Information was stored in Excel database, ordered and presented in tables to allow good visualization of the set of assessed variables. Chi-squared test and
Cramer's V analysis were adopted for statistical analysis.

The research was conducted based on ethical precepts, it respected all the ethical principles of animal experimentation elaborated by the Brazilian School of Animal Experimentation (COBEA), which was protocolled at the Ethics Committee on Animal Experimentation (CEEA) of Maranhão State University - UEMA under protocol n. 02/2019 and approved by Opinion n. 16/2019.

\section{RESULTS AND DISCUSSION}

Results of abscesses recorded at "observation in vivo" and "post-mortem inspection" applied to bovines after footand-mouth vaccination are described in Table 1.

Table 1. Occurrence of post-vaccination abscesses in bovine subjected to vaccination against foot-and-mouth disease, São Luís - MA.

\begin{tabular}{c|cc|cc}
\hline \multirow{2}{*}{ GROUPS } & \multicolumn{2}{|c|}{$\begin{array}{c}\text { Observation carried out } \\
\text { between 7 and 45 days after } \\
\text { vaccination (in vivo) }\end{array}$} & $\begin{array}{c}\text { Observation after slaughter } \\
\text { (post-mortem }\end{array}$ & \\
\cline { 2 - 5 } & $\begin{array}{c}\text { Animspection) } \\
\text { without }\end{array}$ & $\begin{array}{c}\text { Animals } \\
\text { without } \\
\text { abscess }-\mathrm{n}(\%)\end{array}$ & $\begin{array}{c}\text { Animals } \\
\text { without } \\
\text { abscess }-\mathrm{n}(\%)\end{array}$ & $\begin{array}{c}\text { Animals } \\
\text { without abscess } \\
\text { absess }-\mathrm{n}(\%)\end{array}$ \\
\hline G1 & $9(90)$ & $6(60)$ & $6(60)$ & $9(90)$ \\
G2 & $8(80)$ & $5(50)$ & $5(50)$ & $8(80)$ \\
G3 & $7(70)$ & $4(40)$ & $4(40)$ & $7(70)$ \\
\hline
\end{tabular}

Group 1 presented abscess formation in $1(10 \%)$ bovine in the "observation in vivo" period. Groups 2 and 3 presented abscess formation in $2(20 \%)$ and 3 $(30 \%)$ bovines, respectively. Groups 1 and 3 did not present vaccine reaction in the first observation that was significant enough to indicate abscess formation; abscesses were only observed in the second (28 days) and third observations
(45 days). As for Group 2, it was possible observing abscess formation in one animal since the first observation ( 7 days). It is important highlighting that the size of the identified abscesses ranged from 2 to $10 \mathrm{~cm}$.

Local foot-and-mouth vaccine reaction is expected, even if recommendations about the proper vaccine administration and measures to be taken throughout 
vaccination are adopted. Vaccineproduction care, vaccine lot acquisition and storage, as well as appropriate animal contention, the correct choice for administration route and vaccine administration based on good hygienic and sanitary practices avoid stress to animals and significantly reduce the emergence of inflammatory lesions that depreciate the final value of the carcass and generate significant losses for breeders, in the mid- and long-term (LORENÇATO et al., 2018).

Lima and collaborators (2014) assessed nodule occurrence after vaccination by using the old formulation of the footand-mouth disease vaccine (with saponin). They observed that animals subjected to the administration of the vaccine through subcutaneous route have shown greater post-vaccination reaction than animals subjected to intramuscular administration.

Saponin removal, as well as immunization dose reduction to $2 \mathrm{~mL}$ of foot-and-mouth disease vaccine, implied important discussions among animal health defense bureaus and vaccine producers. Brazil faced sanitary embargoes in 2017, the United States canceled beef (in natura) imports due to excess of abscesses in the sparerib, palette and neck regions (CAN, 2017). However, it is known that the emergence of these lesions is not only related to vaccine compounds and dose. Sanitary management during the immunization process also has significant relevance in local inflammatory reactions that boost the emergence of vaccine abscesses (MONTE et al., 2018).

After slaughtering, it was possible observing abscess formation in the carcasses during "post-mortem inspection" (Figure 1), including the carcass of animals who did not present visible or palpable abscesses during "observation in vivo" - results showed $40 \%$ of carcasses with abscesses in Group 1, 50\% in Group 2 and $60 \%$ in Group 3 (Table 1). The Chi-squared test and the Cramer's V analysis did not evidence significant difference in results for vaccine abscess occurrence in the three experimental groups. The smallsized sample used in the current study may be a limiting factor for the identification of statistical difference among compared groups. 


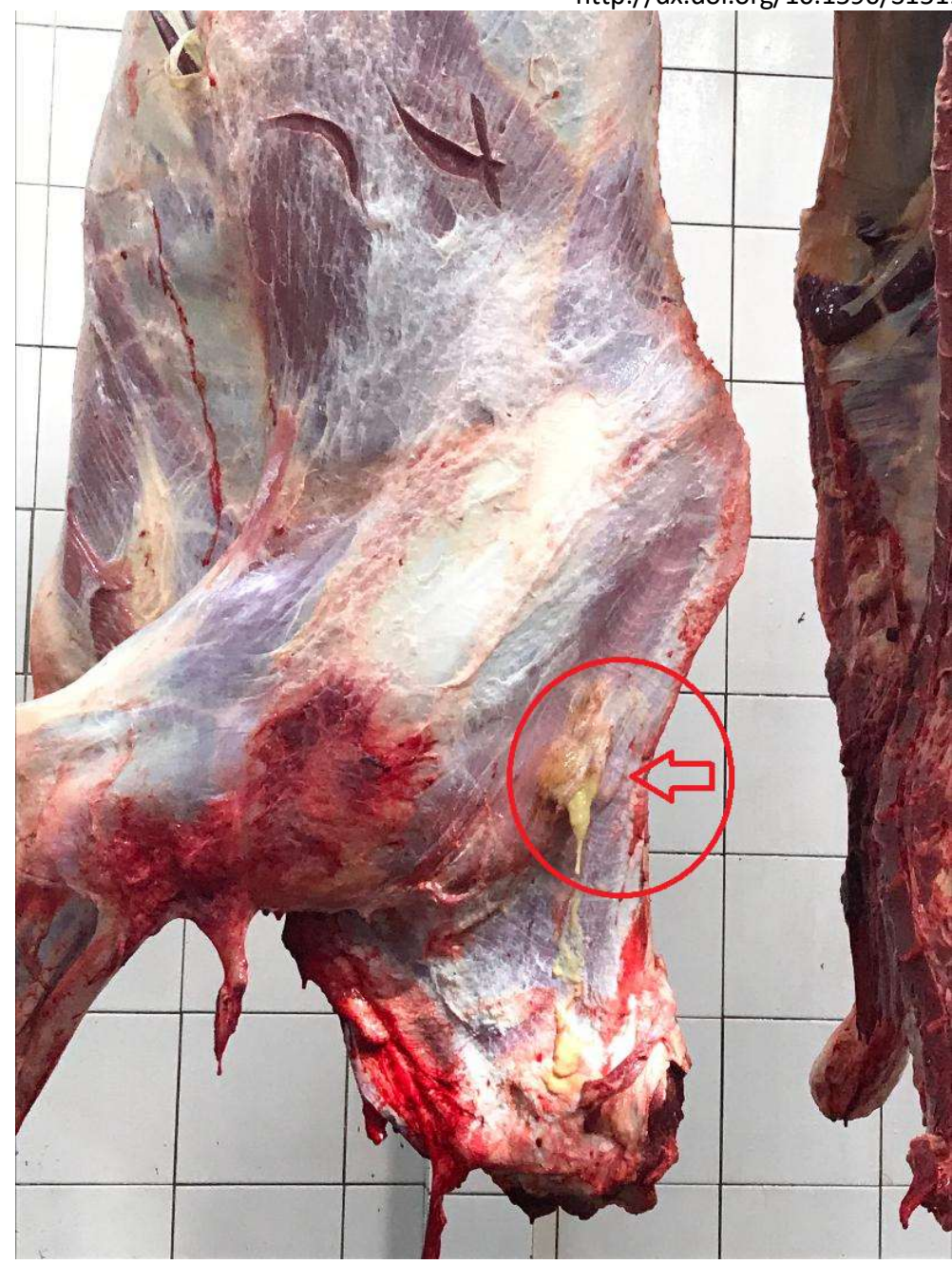

Figure 1. Bovine carcass presenting spilling abscess in the cervical region

Source: Experiment images, 2019

A study carried out in a slaughterhouse under federal inspection service found results similar to those in the current study; $45.25 \%$ of carcasses presenting one, or more, vaccine abscesses (LORENÇATO et al., 2018). Losses caused by different lesion types pointed towards the presence of abscesses in the front side in $45 \%$ of the 1,730 assessed half-carcasses in the slaughterhouse (LIMA et al., 2019).

Previous research pointed out the neck region as the area presenting the highest occurrence of abscesses likely related to adverse reaction to vaccination and/or to medicine administration. Melo et al.
(2015) assessed the economic impact of abscess presence and observed higher prevalence of lesions in the front quarter of carcasses. The mostly affected regions were neck (81.57\%) and sparerib $(16.28 \%)$. The emergence of lesions was related to inappropriate vaccine management. Leal et al. (2014) recorded greater occurrence of abscesses in the cervical regions by estimating losses caused by granulomatous reaction in bovines. They found consistent, circumscribed nodules, with purulent material; abscesses were observed in $54.17 \%$ of the total of 3,350 inspected carcasses. 
Meat parts removed from the carcasses presenting abscesses were individually weighed in each experimental group. The value paid to breeders in the experimental region - which corresponded to $\mathrm{R} \$ 10.50 / \mathrm{kg}$ in 2019 was adopted to estimate economic losses in cattle slaughter due to lesions caused by foot-and-mouth disease vaccination (Table 2).

Table 2. Economic losses caused by meat parts removed from carcasses in order to excise abscesses in bovines subjected to vaccination against foot-and-mouth disease, São Luís - MA.

\begin{tabular}{cccccc}
\hline GROUPS & $\begin{array}{c}\text { N. of } \\
\text { animals } \\
\text { with } \\
\text { abscess }\end{array}$ & $\begin{array}{c}\text { Total of } \\
\text { excised } \\
\text { tissue }(\mathrm{Kg})\end{array}$ & $\begin{array}{c}\text { Mean of } \\
\text { excised } \\
\text { tissue/animal } \\
(\mathrm{Kg} / \text { animal })\end{array}$ & $\begin{array}{c}\text { Loss per } \\
\text { animal* } \\
(\mathrm{R} \$ / \mathrm{Kg})\end{array}$ & $\begin{array}{c}\text { Total loss of } \\
\text { the group* } \\
\text { (R\$) }\end{array}$ \\
\hline G1 & 4 & 1.775 & 0.444 & 4.66 & 18.64 \\
G2 & 5 & 2.303 & 0.461 & 4.84 & 24.18 \\
G3 & 6 & 3.268 & 0.545 & 5.72 & 34.31 \\
\hline
\end{tabular}

*The value $/ \mathrm{Kg}$ adopted in the experimental region was used - $\mathrm{R} \$ 10.50$ for front side meat.

Group 3 recorded the greatest occurrence of abscesses and, consequently, it also showed the largest amount of removed meat parts; mean of $0.545 \mathrm{Kg} / \mathrm{animal}$, thus totaling $3.268 \mathrm{Kg}$ in the experimental group. This outcome highlighted economic loss of $\mathrm{R} \$ 34.31$ (Thirty-four reais and thirty-one cents). Research carried out in Barretos County - SP showed the loss of meat part removed due to abscess occurrence at the order of $0.236 \mathrm{~kg} /$ carcass among animals inspected in the slaughter line of the municipal slaughterhouse (ASSIS et al., 2011).

Greater losses were recorded by Assunção et al. (2011), who have assessed a slaughterhouse located in Sinop County - MT. They found losses of excided meat due to the occurrence of abscesses presenting mean weight of $1.28 \mathrm{Kg}$ /animal. Araújo et al. (2017) assessed economic losses caused by lesions deriving from vaccine and/or medicine reactions in a slaughterhouse located in Bagé City - RS. They found the incidence of lesions in the neck board region in $66 \%$ of the assessed carcasses. The neck board was the region chosen for the administration of injectable medicines and for vaccine administration. Estimates show total discharge weight of $414.1 \mathrm{Kg}$ and mean loss of $1.16 \mathrm{Kg}$ per animal.

Meat and economic losses recorded for the experimental model can be apparently small; however, it is necessary taking into account that vaccination against foot-and-mouth disease is compulsory in Brazil and that vaccine administration conditions in place follow one of the models used in the experimental groups. The impact of the loss at real scale was simulated through proportionality calculations (Table 3). Therefore, the mean daily slaughter in the slaughterhouse where the experiment was carried out -100 animals/day, 24 days of slaughter per month, value paid for producer per bovine-meat $\mathrm{Kg}$ in the study area corresponded to R $\$ 10.50$ in 2019 - was taken into consideration. 
Table 3. Simulation of economic loss caused by abscess occurrence in bovine subjected to vaccination against foot-and-mouth disease by taking into account a slaughterhouse capable of slaughtering 100 animals per day.

\begin{tabular}{lrrr}
\hline \multirow{2}{*}{\multicolumn{1}{c}{ ITEM }} & \multicolumn{3}{c}{ SIMULATION / SITUATION } \\
\cline { 2 - 4 } & G1 & G2 & G3 \\
\hline Total of slaughtered animals/day & 100 & 100 & 100 \\
Percentage of animals with abscesses (\%) & 40 & 50 & 60 \\
Total of animals with abscesses & 40 & 50 & 60 \\
Mean weight of excided tissue (Kg/animal) & 0.444 & 0.461 & 0.545 \\
Total weight of excided tissue (Kg) & 17.76 & 23.05 & 32.7 \\
Total loss**/day (R\$) & 186.48 & 242.03 & 343.35 \\
Total loss/month*** (R\$) & $4,475.52$ & $5,808.72$ & $8,240.40$ \\
Total loss/year (R\$) & $\mathbf{5 3 , 7 0 6 . 2 4}$ & $\mathbf{6 9 , 7 0 4 . 6 4}$ & $\mathbf{9 8 , 8 8 4 . 8 0}$ \\
\hline
\end{tabular}

* Numbers obtained through results recorded for groups used in the experiment;

**The value/Kg used in the experimental region was adopted - $\mathrm{R} \$ 10.50$ for front side meat; $* * * 24$ days of slaughter per month.

Loss simulation in this slaughterhouse could reach the order of $\mathrm{R} \$ 98,884.80$. The considered economic loss could have been turned into profit to breeders or even into investment in the herein assessed production chain. Lorençato et al. (2018) assessed a slaughterhouse that slaughters 8,000 carcasses/month, on average, and found estimated economic loss, due to meat-loss caused by vaccine abscesses, at the order of $\mathrm{R} \$$ 8,719.20/month and R\$ $104,630.40$ /year, when the value of $\mathrm{R} \$$ 138.00 paid per "arroba" of fat cattle in March 2018, in Minas Gerais State, was taken into account.

Silva et al. (2018) measured economic losses (caused by abscesses indicative of vaccine reaction) in a slaughterhouse registered at SIF. They took into consideration the mean monthly slaughter of 36,000 bovine carcasses and estimated loss due to carcass condemnation or to the condemnation of part of carcasses at the order of 654,264.00/month. This number represents annual extrapolated loss of $\mathrm{R} \$$ 7,851,168.00. Researchers have reported that these costs are afforded by breeders, since half-carcasses are only weighed after all the contaminating content in the abscess is removed.

It is important highlighting that throughout the vaccination stage and up to 60 (sixty) days after its end, animals for immediate slaughter were free from mandatory vaccination against foot-andmouth disease, as addressed in item II of art. 20 of IN 44/2007, which allows breeders to select animals for slaughter in this period. This process can minimize losses due to eventual abscess formation caused by vaccination (BRASIL, 2007). The recorded results show that the intramuscular route presents lower nodule occurrence likelihood after the administration of bivalent foot-andmouth vaccine than the subcutaneous route. However, new studies must be carried out in order to improve clinical follow-up and to assess the effects of bivalent vaccination, by taking into 
account the sectorial needs and the sanitary strategy adopted to eradicate the disease. It is important highlighting the need of intensifying technical guidelines to breeders and keepers about good vaccination practices in rural properties in order to minimize economic losses in beef production chain.

\section{ACKNOWLEDGEMENT}

Authors in the current study are grateful to the State Agency of Livestock Defense in Maranhão - AGED for the support provided for study conduction; to Municipal Agriculture, Fish and Supply Secretariat of São Luís - MA (SEMAPA), which is responsible for the Municipal Inspection Service, for authorizing activities in the slaughterhouse under its management. Thanks to Foundation for Support to Research and Scientific and Technological Development of Maranhão - FAPEMA for the financial support to the publication of this article.

\section{REFERENCES}

AMORIM, E.P.; BASSANI, C.A.; PROHMANN, P.E.; PIANHO, C.R. Reações vacinais e suas perdas econômicas em bovinos abatidos em um frigorífico de Campo Mourão - PR. In: Congresso Científico da Região Centroocidental do Paraná, 3, 2009, Campo Mourão, PR. Anais... Campo Mourão, 2009.

ARAÚJO, L.P.; MOREIRA, S.M.; MORAES, R.E.; ZANUSSO, J.T.; SILVEIRA, I.D.B. Reações vacinais e/ou medicamentosas em carcaças bovinas na região da campanha do Rio Grande do sul. Redvet. v. 18. n. 01. 2017.
ASSIS, D.R.; REZENDE-LAGO,

N.C.M.; MARCHI, P.G.F.; D'AMATO, C.C.D. Perdas econômicas por abscessos e hematomas em carcaças de bovinos. Rev. Portuguesa de Ciências Veterinárias. Lisboa, v.2, n.6, p 47-51. 2011.

ASSUNÇÃO, T.I.; PACHEMSHY, J.A.S.; ANDRADE, E.A.; SILVA, N.AM. Perdas econômicas resultantes de reações vacinais em carcaças de bovinos da raça Nelore. Rev. Bras. de Saúde Produção Animal, Salvador, v.2, n.2, p. 375-380, abr/jun. 2011.

BRASIL. Ministério da Agricultura, Pecuária e Abastecimento. Instrução Normativa $\mathrm{N}^{\circ} 44$, de 02 outubro de 2007. Aprova as diretrizes gerais para a Erradicação e a Prevenção da Febre Aftosa, a serem observados em todo o Território Nacional, com vistas à implementação do Programa Nacional de Erradicação e Prevenção da Febre Aftosa (PNEFA), conforme o estabelecido pelo Sistema Unificado de Atenção à Sanidade Agropecuária. 2007. Acesso em 10 junho de 2020.

Disponível em:

https://www.legisweb.com.br/legislacao /?id=77085.

BRASIL. Ministério da Agricultura Pecuária e Abastecimento. Decreto 9.013/2017. Aprova o Regulamento de Inspeção Sanitária e Industrial dos Produtos de Origem Animal RIISPOA. 2017. Acesso em 18 março de 2019. Disponível em:

http://www.in.gov.br/materia//asset publisher/Kujrw0TZC2Mb/conte nt/id/20134722/do1-2017-03-30decreto-n-9-013-de-29-de-marco-de2017-20134698. 
BRASIL. Ministério da Agricultura, Pecuária e Abastecimento. Instrução Normativa $\mathrm{N}^{\circ} 11$, de 18 janeiro de 2018. Aprova o Regulamento Técnico para a Produção, Controle da Qualidade, Comercialização e Emprego de Vacinas contra a febre aftosa. 2018. Acesso em 24 outubro de 2019. Disponível em:

http://www.aged.ma.gov.br/files/2014/0 1/DOU-de-22.01.2018-IN-

11 Regulamento t $\% \mathrm{C} 3 \% \mathrm{~A} 9 \mathrm{cnico}$ vaci na_aftosa.pdf.

CNA, Confederação da Agricultura e Pecuária do Brasil. Nota Técnica $\mathbf{N}^{\circ}$ 30/2017 da CNA de 10 de julho de 2017. Reações adversas à vacina contra Febre Aftosa. 2017. Acesso em 22 março de 2019. Disponível em: https://www.agricultura.rs.gov.br/uploa d/arquivos/201711/24091100-nt-cnareacao-vacinal.pdf.

FRANÇA FILHO, A.T.; ALVES, G.G.; MESQUITA, A.J.; CHIQUETTO, C.E.; BUENO, C.P.; OLIVEIRA, A.S.C.

Perdas econômicas por abcessos vacinais e/ou medicamentosos em carcaças de bovinos abatidos no estado de Goiás. Ciência Animal Brasileira. Goiânia, v. 7, n. 1, p. 93-96, 2006.

GARCIA, D.C.C.; CORDEIRO DE SÁ, C.G.V.; MCMANUS, C.M.; MELO, C.B. Impactos do Surto de Febre Aftosa de 2005 Sobre exportações de Carne Bovina. Cienc. Anim. Bras., Goiânia, v.16, n.4, p. 525-537 out./dez. 2015.

GASPAR, E.B.; MINHO, A.P;

SANTOS, L.R. Manual de Boas

Práticas de Vacinação e Imunização de Bovinos. Circular Técnica da EMBRAPA n ${ }^{\circ}$ 5. Bagé, RS. Ago. 2015.
LEAL, P.V.; PUPIN, R.C.; SANTOS, A.C.; FACCIN, T.C.; SURDI, E.; LEAL, C.R.B.; BRUMATTI, R.C.; LEMOS, R.A.A. Estimativas de perdas econômicas causadas por reação granulomatosa local após uso de vacina oleosa contra febre aftosa em bovinos de Mato Grosso do Sul. Pesq. Vet. Bras. v.34, n.8, p.738-742, 2014. LIMA, D.C.P.; COSTA, A.S.; FERREIRA, M.D.S.; SOBRINHO, J.M.F. Febre Aftosa: ocorrência de nódulo pós-vacinal segundo via de aplicação da vacina. Pesq. Agrop. Gaúcha, Porto Alegre, v.20, n.1/2, p.167-172, 2014.

LIMA, L.G.F.L.; BUENO, C.C.F.; RODRIGUES, L. GONTIJO, L.M.A.; FERRO, D.A.C.; COELHO, K.O.; PEREIRA, N.M.; MIYAGI, E.S.; SILVA, C.C.S.; PAULA, R.S. Perdas ocasionadas por lesões em carcaças em matadouro-frigorífico no estado de Goiás. Semina: Ciências Agrárias, Londrina, v.40, n.6, supl. 3, p.37293740, 2019.

LORENÇATO, E.G.; LUCCI, J.R.; SANTOS, E.M.P.D.; DIAS, A.M.N. Prejuízo econômico por abscessos vacinais retirados de carcaças de bovinos em um frigorífico sob serviço de inspeção federal em Minas Gerais. Higiene Alimentar. v.32, n.286-287, p.142-146. 2018.

MARANHÃO. Agência Estadual de Defesa Agropecuária. Resultado oficial primeira etapa de vacinação contra a febre aftosa no Maranhão. 2019. Acesso em 10 agostos de 2019. Disponível em: http://www.aged.ma.gov.br/febreaftosa-pnefama/. 
MELO, W.O.; SANTOS, E.A.; ABUD, L.J.; COELHO, G.J.; SANTOS, S.C.;

ALMEIDA, L.R.R.; GOUVEA, M.A.; VIEIRA, I.A.; MONTEIRO, B.M. Impacto econômico da ocorrência de lesões em carcaças de bovinos abatidos no sudoeste do Pará. Acta Veterinaria Brasilica, v.9, n.3, p.243-250, 2015. MONTE, G.L.S.; PALUDO SCHULTZ, W.; FERREIRA-NETO, V. Ocorrência de abscessos vacinais e/ou medicamentosos em carcaças de bovinos abatidos no município de Iranduba, Amazonas, Brasil. Revista Científica de Medicina Veterinária. v.10, n.30, p.1-7, 2018.

MORO, E.; JUNQUEIRA, J.O.B.; UMEHARA, O. Levantamento da incidência de reações vacinais e/ou medicamentosas em carcaças de bovinos na desossa em frigoríficos no Brasil. A Hora Veterinária, v.123, p. 55-57, set/out. 2001.

SILVA, T.V.C.; SOUSA, U.A.; MENDONÇA, M.; TORRES, M.B.A.M.; FRANQUE, M.P. Perdas econômicas causadas por lesões nodulares características de reação vacinal contra febre aftosa em bovinos abatidos em mato Grosso do Sul, Brasil. Higiene Alimentar, v.33, p.1967-1921, 2019. 